\title{
PELATIHAN DAN PEMBIMBINGAN DESAIN GRAFIS UNTUK MENINGKATKAN KEMAMPUAN SISWA
}

\author{
Nurlaily Vendyansyah ${ }^{1}$, Peniel Immanuel Gultom ${ }^{2}$ \\ ${ }^{1}$ Teknik Informatika, Institut Teknologi Nasional Malang \\ ${ }^{2}$ Teknik Mesin, Institut Teknologi Nasional Malang \\ nurlaily.vendyansyah@lecturer.itn.ac.id
}

\begin{abstract}
ABSTRAK
Salah satu upaya pemerintah dalam rangka meningkatkan kualitas pendidikan di negaranya adalah dengan melakukan kompetisi di bidang IPTEK (Ilmu Pengetahuan dan Teknologi). Di Indonesia, pemerintah melakukan kegiatan rutin yang dilaksanakan setiap tahun sekali. Kegiatan ini dikenal dengan nama Lomba Kompetensi Siswa yang kemudian populer dengan nama LKS. LKS adalah kompetisi tahunan antar siswa pada jenjang SMK sesuai bidang keahlian yang diajarkan pada SMK peserta. Dalam kegiatan pengabdian kepada masyarakat ini, mitra merupakan salah satu sekolah favorit swasta yang terletak di Kota Malang yaitu Sekolah Menengah Kejuruan (SMK) Nasional Malang yang aktif ikut serta dalam kompetisi LKS. Keberhasilan dalam kompetisi LKS adalah iming-iming popularitas sekolah di mata masyarakat selain perolehan penghargaan resmi oleh Kemendikbud. Namun selama mengikuti kegiatan LKS, mitra belum pernah mendapatkan juara. Hal inilah yang mendorong kuat SMK Nasional untuk terus memperbaiki diri, salah satunya adalah dengan cara melakukan kerjasama dengan Perguruan Tinggi di Kota Malang. Pada tahun 2020 mitra mengikuti LKS dalam bidang Teknik Desain Laman. ITN Malang dipilih karena memiliki jurusan Teknik Informatika dengan kurikulum yang dianggap mampu melakukan pembimbingan untuk siswanya. Proses pembimbingan dilakukan dengan memberikan short course untuk guru pendamping dan siswa yang ikut LKS. Dalam pelaksanaannya diperlukan analisis kebutuhan materi yang diperlukan untuk menunjang kemantapan dalam menghadapi LKS. Hal ini diperlukan untuk membuat rancangan materi agar dapat menyusun modul pembelajaran yang nantinya dipergunakan sebagai pendamping panduan proses pembelajaran pada short course desain grafis menggunakan Adobe Photoshop. Pada akhir short course dilakukan evaluasi untuk mengetahui perkembangan kemampuan siswa. Hasil menunjukkan 29,23\% mengalami peningkatan pemahaman materi.
\end{abstract}

Keyword : Adobe Photoshop, desain grafis, kursus pendek, multimedia, website

\section{PENDAHULUAN}

Salah satu upaya pemerintah dalam rangka meningkatkan kualitas pendidikan di negaranya adalah dengan melakukan kompetisi di bidang ilmu pengetahuan dan teknologi, yang kemudian di imingimingi dengan hadiah. Begitu juga dengan tanah air kami tercinta yaitu Indonesia. Berbagai cara dilakukan untuk memenuhi kebutuhan tersebut. Di Indonesia, pemerintah telah melakukan kegiatan rutin yang dilaksanakan setiap tahun sekali. Kegiatan ini dikenal dengan nama Lomba Kompetensi Siswa yang kemudian populer dengan nama LKS.

LKS merupakan kompetisi antar siswa khusus sekolah menengah kejuruan (SMK) sesuai bidang keahlian yang diajarkan di SMK (SMK, A. P, 2020). Kegiatan LKS ini merupakan kegiatan yang paling populer di lingkungan SMK. Semua SMK berlomba untuk dapat berpartisipasi dalam kompetisi nasional ini, dengan 47 bidang yang diperlombakan pada tahun 2020 . Kegiatan LKS ini merupakan salah satu wujud usaha Kementrian Pendidikan dan Kebudayaan (Kemendikbud) dalam memberikan dukungan dan motivasi kepada siswa Sekolah Menengah Kejuruan (SMK) dalam rangka menanamkan karakter positif, dan meningkatkan kompetensi. LKS merupakan kompetisi nasional bergengsi yang telah berlangsung sejak tahun 1992.

Hingga kini LKS telah mengalami perkembangannya yang cukup pesat. Saat ini LKS sudah masuk pada kompetisi tingkat internasional dengan melibatkan negara ASEAN yang tergabung dalam SEACC atau South East Asia Creative Camp. Dalam pelaksanaannya LKS dibagi berdasarkan pembagian wilayah kerja sesuai peraturan Kemendikbud. Alasan-alasan itulah yang menjadi sebab sekolahsekolah yang berada di wilayah 7 Indonesia semakin mempersiapkan diri untuk dapat ikut serta dalam kegiatan LKS.

Seperti salah satu Sekolah Menengah Kejuruan (SMK) yang berada di Kota Malang, yaitu SMK Nasional. SMK ini merupakan sekolah swasta kejuruan di Kota Malang yang selalu aktif ikut serta dalam berbagai kompetisi. Prestasi adalah alasan utama yang kemudian akan digunakan untuk mengukur kemampuan siswa di sekolahnya, untuk selanjutnya dipergunakan sebagai dasar pembentukan rencana strategi dalam menyusun rencana pembelajaran untuk mata pelajaran. Tentunya startegi yang dilakukan oleh SMK Nasional merupakan startegi yang sangat baik, sehingga dapat digunakan sebagai evaluasi hasil pembelajaran yang telah dilakukan. Alasan lainnya adalah nilai atau pamor SMK Nasional di mata masyarakat akan semakin meningkat. Hal ini tentunya berdampak pada startegi pemasaran SMK, mengingat SMK Nasional adalah sekolah swasta kejuruan yang dapat digunakan untuk memberikan keyakinan kepada masyarakat untuk memberikan 
kepercayaan serta tertarik untuk menitipkan putra putrinya untuk dapat di didik di SMK Nasional. Alasan selanjutnya adalah bahwa SMK Nasional malang merupakan sekolah tertua di Kota Malang yang berdiri pada tanggal 17 Juli 1951. SMK Nasional Malang terletak di jantung Kota Malang, tepatnya di jalan Raya Langsep No 43. Di mata masyarakat SMK Nasional masih menjadi pilihan favorit untuk kategori Sekolah Menengah Kejuruan di Kota Malang dengan delapan bidang keahlian yang ditawarkan dengan kualitas baik.

Dalam usaha aktif ikut serta dalam berbagai kompetisi, tentunya SMK Nasional harus mempersiapkan diri sebaik mungkin. Seperti kendala yang dihadapi dalam mempersiapkan keikutsertaanya dalam kompetisi LKS. Permasalahan yang muncul pada smitra adalah mitra SMK ini memiliki keinginan untuk mengikuti kegiatan lomba yang terkait desain grafis dengan aplikasi grafis yang harus ditanamkan dalam website, akan tetapi dalam lomba tersebut memiliki tantangan salah satunya pembuatan desain grafis dengan aplikasi grafis yang harus ditanamkan dalam website tersebut. Sedangkan SDM yang dimiliki sekolah tersebut masih kesulitan untuk saat ini dalam memberikan materi tersebut kepada siswa, dikarenakan materi tersebut masih belum ada pada kurikulum nasional untuk SMK.

Berdasarkan hasil survey maka dapat dilakukan identifikasi permasalahan adalah sebagai berikut :

1. Kemampuan siswa pada sekolah mitra yang dipersiapkan sebagai peserta dianggap masih belum mampu untuk dapat bersaing dalam menghadapi LKS.

2. Peserta yang dipersiapkan untuk mengikuti LKS hanya satu orang.

3. Peserta yang dipersiapkan oleh mitra dalam menghadapi LKS juga diprioritaskan untuk menghadapai lomba lainnya.

4. Peserta yang dipersiapkan oleh mitra dalam menghadapi LKS dan lomba lainnya adalah siswa kelas XII, yang tentunya juga harus mempersiapkan diri dalam Ujian Nasional untuk menentukan kelulusan.

5. Keputusan kelulusan Ujian Nasional pada SMK Nasional Malang, tidak dipengaruhi oleh pretasi lomba yang pernah diikuti oleh siswa.

6. Tenaga pengajar pada mitra masih belum memiliki keterampilan yang mumpuni dalam kasus Desain Grafis menggunakan Adobe Photoshop.

7. Tenaga pengajar pada mitra masih belum mempersiapkan modul ajar untuk persiapan LKS.

8. Budaya siswa pada sekolah mitra yang masih dianggap belum layak untuk mengikuti lomba seperti LKS.

9. Pada sekolah mitra, siswa dianggap mampu dalam suatu materi apabila siswa tersebut telah dapat meniru. Hal ini dianggap masih tidak layak untuk maju ke pertandingan.

Perumusan masalah pada kegiatan ini adalah sebagai berikut :

1. Bagaimana membuat Short Course yang ditujukan pada mitra agar mampu bertanding dalam menghadapi LKS ?

2. Bagaimana membuat modul pembelajaran tentang yang mudah dipahami dalam waktu singkat untuk siswa pada sekolah mitra tentang materi desain grafis menggunakan Adobe Photoshop yang ditanamkan pada website, sesuai tema LKS yang dipilih oleh mitra yang telah ditentukan oleh Kementerian Pendidikan dan Kebudayaan (Kemendikbud) ?

\section{TINJAUAN PUSTAKA}

\subsection{Short Course}

Short Course atau kursus pendek ialah salah satu jenis model pembelajaran yang dilakukan dengan durasi singkat, biasanya satu minggu hingga delapan minggu. Bentuk kursus pendek dapat berupa pertukaran pelajar/mahasiswa, pelatihan atau bahkan pengenalan budaya. Hampir semua universitas atau prguruan tinggi baik negeri maupun swasta di Indonesia yang menyediakan kursus pendek dengan tidak meberikan pungutan biaya. Biasanya dilakukan sebagai bentuk pengabdian kepada masyarakat yang memiliki tujuan untuk mencerdaskan kehidupan bangsa (Kursus,2020).

\subsection{Desain Grafis}

Desain grafis adalah salah satu cabang dari ilmu multimedia. Sesuai dengan namanya frasa desain grafis berasal dari kata "design" yang artinya rencana, rancangan dan "graphic" yang artinya yang berhubungan dengan tulisan tangan. Secara harfiah desain grafis adalah seni tulisan tangan atau coretan tangan (Meggs, Philip B., dan Alston W. Purvis, 2006). Namun dengan perkembangan ilmu pengetahuan dan teknologi, desain grafis saat ini dilakukan melalui komputer. Banyak perangkat lunak komputer yang mampu melakukan fungsi desain grafis, seperti corel draw, adobe photoshop, dsb(Ze-Nian Li, Mark,S.Drew, 2003). Saat ini ilmu desain grafis banyak digunakan oleh editor, animator, fotografer, layouter, serta art director (Williams, James Lamar, 2012). Saat ini profesi yang ahli dalam bidang desain grafis banyak dicari dan digemari oleh masyarakat. Alasan utamanya adalah seni yang tidak dapat dipelajari sehingga membuat hasil karya atau produk dari desain grafis bernilai tinggi. Namun pada dasarnya desain grafis dapat dipelajari. Alasan-alasan itulah yang membuat ilmu desain grafis semakin banyak diminati oleh masyarakat.

\subsection{SMK Nasional}

SMK Nasional Malang merupakan lembaga pendidikan tertua di kota Malang dibawah yayasan 
P2PUTN (Perkumpulan Pengelola Pendidikan Umum dan Teknologi Nasional). SMK Nasional merupakan Sekolah Menengah Kejuruan yang berdiri sejak tahun 1951 yang beradada di Jalan Raya Langsep 43 Bareng, Klojen, Kota Malang . Saat ini SMK Nasional memilik delapan bidang kompetensi keahlian yaitu Teknik Gambar Bangunan (TGB), Teknik Instalasi Tenaga Listrik, Teknik Pemesinan, Teknik Kendaraan Ringan (TKR), Teknik Audio Video, Rekayasa Perangkat Lunak (TPL), Teknik Komputer dan Jaringan (TKJ), serta Multi Media (MM). SMK Nasional siap menghasilkan lulusan yang berkompeten dan berkarakter. Hal ini terbukti dari prestasi yang dimiliki oleh SMK Nasional yang aktif ikut serta dalam berbagai kompetisi (Malang, S.N, 2020).

\subsection{Adobe Photoshop}

Adobe Photoshop merupakan perangkat lunak multimedia yang digunakan untuk mengolah gambar atau image. Perangkat lunak ini banyak diminati oleh para pengembang, karena dapat berjalan pada berbagai sistem operasi komputer yaitu Windows, Linux serta turunannya, maupun Mac OS. Alasan lain yang membuat perangkat lunak banyak digunakan oleh pengembang antara lain IDE (Integrated Development Environment) yang user friendly serta banyaknya fitur yang disediakan untuk melakukan proses editing gambar. (Adobe, 2020)

\section{METODE PENELITIAN}

3.1. Permasalahan dalam bidang sosial pendidikan

SMK Nasional merupakan salah satu sekolah kejuruan milik swasta yang beroperasi di kota malang. Di tengah persaingan yang semakin ketat, sekolah ini juga tidak kalah dengan sekolah kejuruan lainnya. Dengan terus meningkatkan prestasi baik dalam bidang akademik maupun non akademik, baik prestasi yang dicetak oleh staff, karyawan dan guru maupun prestasi yang dicetak oleh siswa. Salah satu kompetisi yang bergengsi adalah Lomba Kompetensi Siswa atau yang dikenal dengan LKS yang diselenggarakan oleh Kemendikbud yang secara konsisten sejak tahun 1992 hingga saat ini.

LKS merupakan kompetisi antar siswa khusus sekolah menengah kejuruan (SMK) sesuai bidang keahlian yang diajarkan di SMK (SMK, A. P, 2020). Kegiatan LKS ini merupakan kegiatan yang paling populer di lingkungan SMK. Semua SMK di Indonesia berlomba untuk dapat berpartisipasi dalam kompetisi nasional ini, dengan 47 bidang yang diperlombakan pada tahun 2020. Kegiatan LKS ini merupakan salah satu wujud usaha Kementrian Pendidikan dan Kebudayaan (Kemendikbud) dalam memberikan dukungan dan motivasi kepada siswa Sekolah Menengah Kejuruan (SMK) dalam rangka menanamkan karakter positif, dan meningkatkan kompetensi. LKS merupakan kompetisi nasional bergengsi yang telah berlangsung sejak tahun 1992. Hingga kini LKS telah mengalami perkembangannya yang cukup pesat. Saat ini LKS sudah masuk pada kompetisi tingkat internasional dengan melibatkan negara ASEAN yang tergabung dalam SEACC atau South East Asia Creative Camp.

Acara tahunan ini ternyata membuat berbagai sekolah kejuruan di seluruh Indonesia dijadikan sebagai acara bergengsi untuk meningkatkan popularitas dan kualitas sekolah di mata masyarakat. Hal ini juga dijadikan sebagai media promosi yang dapat menjual nilai sekolah di mata masyarakat, sehingga dapat memberikan pengakuan terhadap lulusan SMK. Tidak ketinggalan juga untuk SMK Nasional, Kota Malang. Namun untuk menghadapi kompetisi semacam ini diperlukan persiapan yang matang. Target SMK pada Lomba Kompetensi Siswa (LKS) tahun 2020 adalah dapat lolos wilayah kerja 3. Sayangnya resource yang dimiliki oleh sekolah dalam hal ini yang dimaksud adalah guru, dianggap masih belum mampu untuk membimbing siswanya dalam menghadapi kompetisi tersebut.

Berdasarkan informasi yang didapatkan dari wawancara dengan guru yang ditunjuk sebagai guru pendamping, menyatakan bahwa materi yang diujikan pada LKS melebihi kurikulum SMK. Begitu juga untuk pemilihan siswa yang akan dikirim untuk menjadi peserta LKS, mengingat hanya ada satu siswa yang akan mewakili sekolah dalam LKS. Untuk dapat memilih siswa yang dianggap mampu untuk dibina atau diajukan untuk mengikuti pelatihan dalam menghadapi LKS, pihak mitra menganggap yang mampu dan memenuhi kualifikasi tersebut hanyalah siswa yang duduk di kelas XII. Hal ini dianggap sangat mengganggu bagi siswa, karena siswa kelas XII sedang mempersiapkan diri untuk ujian nasional. Permasalahan ini dianggap serius oleh pihak mitra. Di satu sisi sekolah menginginkan untuk unggul dari yang lainnya dengan alasan salah satu cara promosi, disisi lain siswa yang dipersiapkan hanya seeikit yang memiliki kualifikasi untuk dapat mengikuti LKS. Oleh karena itu, mitra dalam hal ini adalah SMK Nasional, Kota Malang mengirimkan permohonan kepada Prodi Teknik Informatika S1, ITN Malang dalam kegiatan bimbingan untuk mengahadapi Lomba Kompetensi Siswa (LKS).

\subsection{Partisipasi mitra dalam pelaksanaan program}

Bentuk partisipasi mitra dalam kegiatan bimbingan untuk menghadapi Lomba Kompetensi Siswa (LKS) yaitu :

a. Mitra mempersiapkan (memilih) siswa yang memiliki kemampuan yang dianggap mampu atau memenuhi kualifikasi dalam persiapan pelatihan atau pembimbingan untuk mengikuti LKS. Siswa tersebut akan mengikuti proses pelatihan yang dilaksanakan di Prodi Teknik Informatika S1, ITN Malang.

b. Mitra mempersipkan atau menunjuk guru pendamping, dan akan mengikuti proses pelatihan yang dilaksanakan di Prodi Teknik Informatika S1, ITN Malang. 
3.3. Evaluasi pelaksanaan program dan keberlanjutan program di lapangan setelah kegiatan PKM selesai dilaksanakan.

Evaluasi yang dilaksanakan dimaksudkan untuk mengetahui apakah tahapan proses yang diterapkan sudah baik atau belum. Tahapan ini dilakukan dengan cara memberikan kuisioner kepada mitra tentang kinerja tim pengabdi. Dan diskusi antar tim pengabdi tentang kendala apasajakah yang dialami selama melakukan proses pengabdian ini. Keberlanjutan program pelatihan di lapangan dilakukan dengan memberikan bekal materi pelatihan dalam bentuk modulyang khusus dipersiapkan untuk menghadapi LKS, sehingga baik siswa maupun guru pendamping dapat mempelajarinya dengan mudah. Pihak mitra juga bermaksud untuk bekerjasama dengan Prodi Teknik Informatika untuk dapat memberikan pelatihan kembali dalam menghadapi Lomba Kompetensi Siswa (LKS) di tahun mendatang.

\subsection{Kerangka Pemecahan Masalah}

Kerangka pemecahan masalah terdiri dari enam tahapan ditunjukkan seperti Gambar 1.

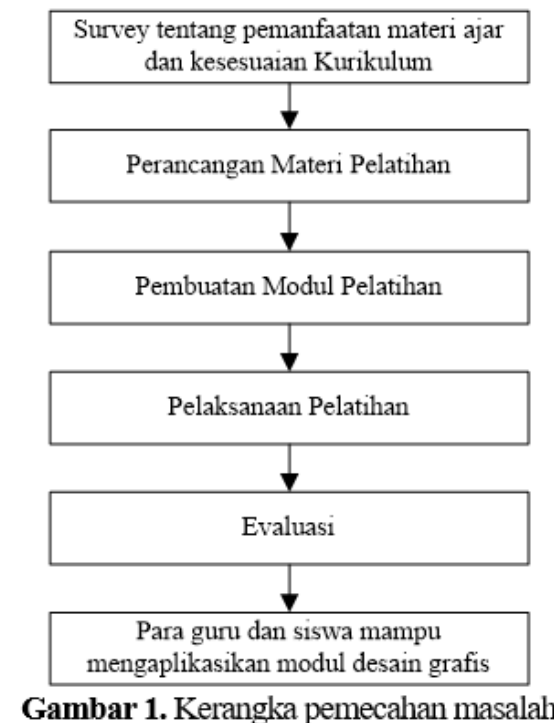

Tahap pertama, survey dilakukan untuk mengetahui permasalahan khusus yang terjadi di sekolah. Pada tahapan ini dilakukan dengan cara wawancara baik kepada siswa dan guru pendamping yang mengampu mata pelajaran di sekolah. Hasil survey dan wawancara dilakukan analisis mengenai kebutuhan materi untuk mendukung siswa dalam menghadapi LKS. Selanjutnya dilakukan perancangan materi dengan memperhatikan kebutuhan mitra untuk kemudian dilakukan penyusunan modul pembelajaran yang nantinya digunakan sebagai materi pendamping kegiatan short course. Pada akhir kegiatan short course dilakukan evaluasi untuk mengetahui kemampuan siswa dalam pemahaman materi dan kemampuan dalam praktik. Pada tahapan ini dilakukan secara iteratif apabila kemampuan siswa dianggap belum maksimal, hingga tercapai tujuan utama yaitu mampu berkompetisi dalam Lomba Kompetisi Siswa.

\subsection{Rancangan Evaluasi}

Rancangan evaluasi digunakan untuk mengetahui apakah Short Course yang telah dilakukan dapat memberikan nilai manfaat terhadap mitra. Dalam hal ini rancangan evaluasi dilakukan terhadap mitra yaitu siswa, guru dan terhadap kepala sekolah yang dapat diberikan penjelasan sebagai berikut :

a. Rancangan evaluasi yang dilakukan terhadap siswa dilakukan dengan cara memberikan simulasi lomba pada setiap akhir pertemuan materi dengan menggunakan timer sesuai materi yang telah dipelajari pada pertemuan tersebut. Dalam proses ini siswa tidak diperkenankan untuk mencontek atau membuka catatan dalam bentuk apapun. Di akhir Short Course, siswa melakukan simulasi final LKS sesuai dengan tema yang telah dipilih menggunakan kisi-kisi yang LKS pada tahun sebelumnya dan menggunakan timer. Proses simulasi final ini ini dilakukan sebanyak 2 kali.

b. Rancangan evaluasi yang dilakukan terhadap guru pengajar mata pelajaran terkait pada sekolah mitra yaitu dilakukan dengan cara diskusi dan memberikan kuisioner kepada guru terhadap cara mengajar kepada siswa oleh tim pengabdi selama proses pembelajaran Short Course dalam menghadapi LKS. Tim pengabdi juga memberikan sharing materi yang dianggap perlu dimasukkan dalam kurikulum materi pelajaran sekolah.

c. Rancangan evaluasi yang dilakukan terhadap kepala sekolah, yaitu dengan diskusi sharing dan memberikan kuisioner cara mengajar kepada siswa oleh tim pengabdi selama proses pembelajaran Short Course dalam menghadapi LKS, serta ketepatan materi yang diberikan oleh tim pengabdi dalam menghadapi LKS.

\section{HASIL DAN PEMBAHASAN}

\subsection{Kondisi Lingkungan Lokasi Pengabdian} Masyarakat

Lokasi mitra pengabdian masyarakat bertempat di alamat Jl. Raya Langsep 43 Malang, Jarak ;12,9 km.

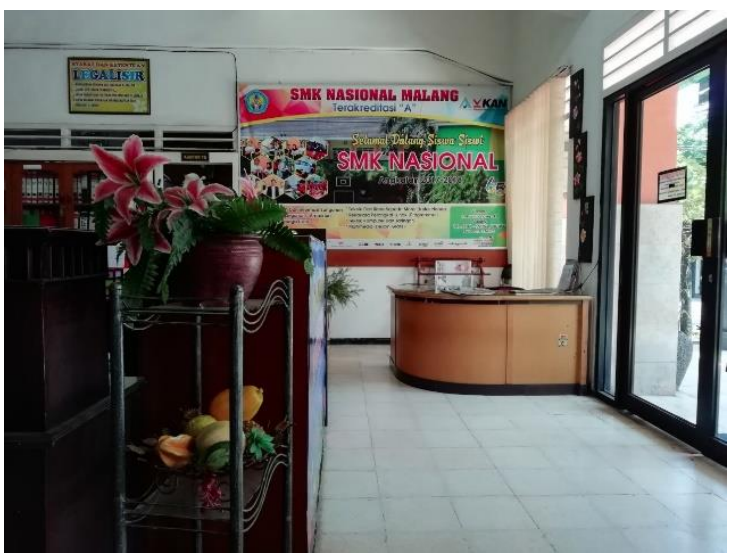

Gambar 2. Lingkungan kegiatan

Kondisi lingkungan kegiatan pengabdian masyarakat seperti ditunjukkan pada Gambar 2. 


\subsection{Kegiatan Pengabdian Kepada masyarakat}

Proses pembelajaran Short Course dibuat seolah menyenangkan namun tetap dapat tercapai targetnya, seperti pada Gambar 3.

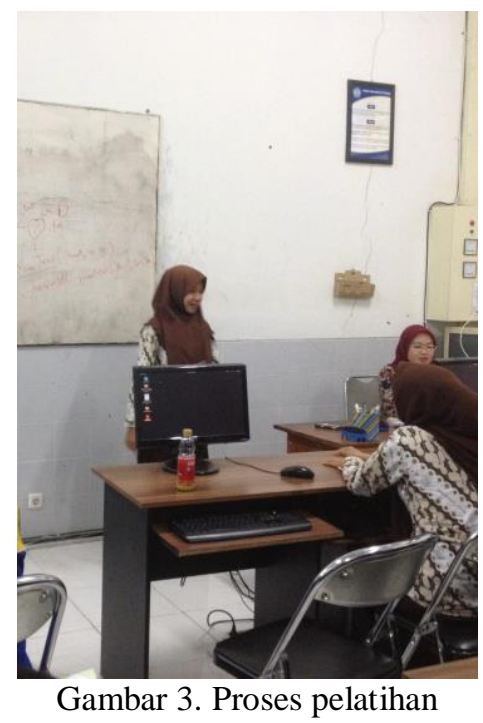

4.3. Hasil pengujian sebelum dilakukan Pelatihan

Untuk mengetahui kemampuan siswa pada mitra sebelum dilakukan Short Course, tim pengabdi melakukan proses pra-evaluasi, yaitu dengan cara memberikan kuisioner kepada 4 siswa pada sekolah mitra yang berisi soal umum mengenai pemahaman desain grafis. Materi soal pra-evaluasi tersebut merupakan materi dasar desain grafis. Hal ini dimaksudkan untuk mengukur kemampuan siswa baik sebelum dan sesudah proses Short Course, dan didapatkan hasil seperti ditunjukkan Tabel 1.

Tabel 1. Hasil pra-evaluasi

\begin{tabular}{|c|c|c|c|c|c|c|}
\hline \multirow{2}{*}{ No. } & \multirow{2}{*}{ Pertanyaan } & \multicolumn{5}{|c|}{ Penilaian } \\
\hline & & $\mathbf{A}$ & B & $\mathbf{C}$ & D & $\mathbf{E}$ \\
\hline 1. & $\begin{array}{l}\text { Bagaimana } \\
\text { pemahaman Anda } \\
\text { tentang multimedia? }\end{array}$ & & 4 & & & \\
\hline 2. & $\begin{array}{l}\text { Bagaimana } \\
\text { pemahaman Anda } \\
\text { tentang desain } \\
\text { grafis? }\end{array}$ & & 4 & & & \\
\hline 3. & $\begin{array}{l}\text { Apakah Anda } \\
\text { mengetahui elemen } \\
\text { dalam membangun } \\
\text { desain grafis? }\end{array}$ & & & 4 & & \\
\hline 4. & $\begin{array}{l}\text { Apakah Anda dapat } \\
\text { membangun produk } \\
\text { desain grafis } \\
\text { sederhana? }\end{array}$ & & 4 & & & \\
\hline 5. & $\begin{array}{l}\text { Apakah Anda dapat } \\
\text { membangun produk } \\
\text { desain grafis } \\
\text { menggunakan }\end{array}$ & & 4 & & & \\
\hline
\end{tabular}

\begin{tabular}{|c|c|c|}
\hline & $\begin{array}{l}\text { software photoshop } \\
?\end{array}$ & \\
\hline 6. & $\begin{array}{l}\text { Apakah Anda dapat } \\
\text { membangun produk } \\
\text { desain grafis 2D } \\
\text { dengan } \\
\text { menggunakan } \\
\text { software photoshop } \\
\text { tanpa mencontek } \\
\text { dalam bentuk } \\
\text { apapun? }\end{array}$ & 4 \\
\hline
\end{tabular}

Keterangan :

A : Sangat Baik

B : Baik

C : Cukup

D : Kurang

E : Sangat Kurang

Berdasarkan pengujian pra-evaluasi diperoleh hasil sebesar 66,6\% siswa peserta Short Course mampu memahami dasar desain grafis dengan baik, namun dengan mencontek. Ketika diberikan pertanyaan nomor 6 siswa peserta Short Course menyatakan $99,83 \%$ siswa kurang mampu dalam membangun produk desain grafis tanpa menggunakan contekan dalam bentuk apapun. Padahal point ini menurut tim pengabdi dianggap paling crusial. Namun hal ini masih perlu dibuktikan dengan proses simulasi LKS dengan menggunakan timer dan soal sesuai kisi-kisi yang diberikan. Karena untuk dapat bersaing dalam kompetisi LKS, siswa harus memiliki kemampuan mahir.

\subsection{Hasil pengujian setelah dilakukan Pelatihan}

Untuk mengetahui kemampuan siswa pada mitra setelah dilakukan Short Course, tim pengabdi melakukan proses post-evaluasi, yaitu dengan cara memberikan kuisioner kepada 4 siswa pada sekolah mitra yang berisi soal mengenai pemahaman desain grafis. Materi soal post-evaluasi tersebut merupakan materi desain grafis sesuai kisi-kisi LKS yang diberikan. Hal ini dimaksudkan untuk mengukur kemampuan siswa baik sebelum dan sesudah proses Short Course, dan didapatkan hasil seperti ditunjukkan Tabel 2.

Tabel 2. Hasil post-evaluasi

\begin{tabular}{|c|l|c|c|c|c|c|}
\hline \multirow{2}{*}{ No. } & \multicolumn{1}{|c|}{ Pertanyaan } & \multicolumn{5}{|c|}{ Penilaian } \\
\cline { 3 - 6 } 1. & $\begin{array}{l}\text { Bagaimana } \\
\text { pemahaman Anda } \\
\text { tentang } \\
\text { multimedia? }\end{array}$ & 4 & B & C & D & E \\
\hline 2. & $\begin{array}{l}\text { Bagaimana } \\
\text { pemahaman Anda } \\
\text { tentang desain } \\
\text { grafis? }\end{array}$ & 4 & & & & \\
\hline 3. & $\begin{array}{l}\text { Apakah Anda } \\
\text { mengetahui elemen }\end{array}$ & 4 & & & & \\
\hline
\end{tabular}




\begin{tabular}{|c|c|c|c|c|}
\hline & $\begin{array}{l}\text { dalam membangun } \\
\text { desain grafis? }\end{array}$ & & & \\
\hline 4. & $\begin{array}{l}\text { Apakah Anda dapat } \\
\text { membangun } \\
\text { produk desain } \\
\text { grafis sederhana? }\end{array}$ & 4 & & \\
\hline 5. & $\begin{array}{l}\text { Apakah Anda dapat } \\
\text { membangun } \\
\text { produk desain } \\
\text { grafis } \\
\text { menggunakan } \\
\text { software photoshop } \\
\text { ? }\end{array}$ & 4 & & \\
\hline 6. & $\begin{array}{l}\text { Apakah Anda dapat } \\
\text { membangun } \\
\text { produk desain } \\
\text { grafis 2D dengan } \\
\text { menggunakan } \\
\text { software photoshop } \\
\text { tanpa mencontek } \\
\text { dalam bentuk } \\
\text { apapun? }\end{array}$ & 3 & 1 & \\
\hline
\end{tabular}

Keterangan :

A : Sangat Baik

B : Baik

C : Cukup

D : Kurang

E : Sangat Kurang

Berdasarkan pengujian post-evaluasi diperoleh hasil sebesar 95,83\% siswa peserta Short Course mampu memahami dasar desain grafis dengan sangat baik tanpa mengunakan contekan dalam bentuk apapun. Hal ini dibuktikan ketika diberikan pertanyaan nomor 6, siswa peserta Short Course menyatakan 99,87\% siswa Sangat Mampu dalam membangun produk desain grafis tanpa menggunakan contekan dalam bentuk apapun. Berdasarkan pengujian yang telah dilakukan dapat disimpulkan bahwa terdapat peningkatan kemampuan siswa pada mitra sebesar 29,23\% mengenai kemampuan desain grafis, sehingga dianggap layak untuk maju sebagai peserta LKS.

\section{KESIMPULAN DAN SARAN}

\subsection{Kesimpulan}

Berdasarkan kegiatan yang telah dilaksanakan maka dapat ditarik kesimpulan sebagai berikut :

1. Berdasarkan pengujian yang dilakukan pada praevaluasi dan post-evaluasi, diketahui bahwa terjadi peningkatan keahlian dalam desain grafis menggunakan shoftware photoshop sebesar $29,23 \%$.

2. Modul pembelajaran Short Course desain grafis dapat digunakan oleh guru pengampu mata pelajaran multimedia sebagai media pendukung kegiatan proses belajar mengajar di sekolah.

\subsection{Saran}

Berdasarkan kegiatan yang telah dilakukan maka dapat diberikan saran sebagai berikut :

1. Proses pembelajaran Short Course agar diberikan waktu yang lebih panjang.

2. Siswa peserta Short Course yang dipersiapkan untuk mengikuti LKS sebaiknya dipilih melalui tes.

3. Jumlah siswa yang akan diikutkan sebagai peserta Short Course yang dipersiapkan untuk mengikuti LKS, sebaiknya jumlahnya disesuaikan dengan ketentuan LKS.

4. Siswa peserta Short Course yang dipersiapkan untuk mengikuti LKS sebaiknya tidak diperkenankan untuk mengikuti lomba lainnya, sehingga siswa dapat fokus untuk satu tujuan.

\section{DAFTAR PUSTAKA}

[1] Adobe. 2020. Adobe Digital Learning Solution. Diambil kembali dari Adobe: https://www.adobe.com/sea/

[2] Kursus. 2020. Diambil kembali dari Kursus: https://id.wikipedia.org/wiki/Kursus

[3] Malang, S. N. 2020. Tentang Kami - SMK Nasional Malang. Diambil kembali dari SMK Nasional Malang: https://smk-nasionalmalang.business.site/

[4] Meggs, Philip B., dan Alston W. Purvis. 2006. Meggs' History of Graphic Design. New Jersey: John Wiley \& Sons, Inc.

[5] SMK, A. P. 2020. LKS NASIONAL. Diambil kembali dari PUSAT PRESTASI NASIONAL KEMENTERIAN PENDIDIKAN DAN KEBUDAYAAN:

https://pusatprestasinasional.kemdikbud.go.id/ 2020/08/07/informasi-bidang-lombakompetensi-siswa-lks-smk-ke-xxviii-tingkatnasional-tahun-2020/. On 11 agustus 2020.

[6] WILLIAMS, James Lamar. 2012. Learning html5 game programming: A hands-on guide to building online games using Canvas, SVG, and WebGL. Addison-Wesley Professional.

[7] Ze-Nian Li, Mark,S.Drew. 2003. Fundamentals of Multimedia. Prentice Hall. 